\title{
Kedudukan Qanun dalam Sistem \\ Pemerintahan Daerah dan Mekanisme Pengawasannya
}

\author{
Jum Anggriani \\ Fakultas Hukum Universitas Tama Jagakarsa Jakarta \\ Letjen T.B. Simatupang No.152 Tanjung Barat- Jakarta Selatan 12530 \\ jumanggriani@yahoo.com
}

\begin{abstract}
This research is focused on the issue of supervision of Qanun as a realization of Central Government authorithy over special autonomy in Nangroe Aceh Darussalam. This research uses analytic descriptive method which gives illustration on scope and opinion of the Central Government supervision over Qanun in Nangroe Aceh Darussalam. This research used juridical normative method as well through legislation approach. This research concludes that for the purpose of supervisory, Central Government may suspend or annul Qanun in the event of contradiction to the related legislation. Preventive supervision is performed on the Regional Government policy which regulates revenue budget and regional expenditure, regional tax, and other regulation that may cause high economical cost.
\end{abstract}

Key words : Qanun, regional government, supervision

\begin{abstract}
Abstrak
Penelitian ini difokuskan pada persoalan pengawasan terhadap Qanun sebagai perwujudan wewenang Pemerintah Pusat terhadap otonomi khusus Nanggroe Aceh Darussalam. Penelitian ini adalah menggunakan metode deskriptif analitis, yaitu penelitian yang memberikan suatu gambaran mengenai ruang lingkup dan tinjauan tentang pengawasan Pemerintah Pusat terhadap Qanun di Nanggroe aceh Darussalam. Penelitian ini juga menggunakan metode yuridis normatif dengan pendekatan perundang-undangan. Penelitian ini menyimpulkan bahwa dalam rangka pengawasan, Pemerintah Pusat dapat menangguhkan atau membatalkan Qanun jika bertentangan dengan peraturan perundangundangan yang mengaturnya. Pengawasan preventif dilakukan terhadap kebijakan Pemerintah Daerah yang mengatur anggaran pendapatan dan belanja daerah, pajak daerah, peraturan lain yang dapat menimbulkan ekonomi biaya tinggi.
\end{abstract}

Kata kunci : Qanun, pemerintah daerah, pengawasan 


\section{Pendahuluan}

Hubungan Pemerintah Pusat dan Daerah telah diatur dalam Pasal 18 UUD 1945 yang kemudian pasal ini diamandemen oleh Majelis Permusyawaratan Rakyat (MPR) pada tanggal 18 Agustus 2000. Pasal 18 ayat (1) UUD 45 menegaskan bahwa Negara Kesatuan Republik Indonesia (NKRI) dibagi atas daerah-daerah provinsi dan daerah provinsi itu dibagi atas kabupaten dan kota, yang tiap-tiap provinsi, kabupaten, dan kota itu mempunyai Pemerintahan Daerah, yang diatur dengan undang-undang. Menurut Jimly Asshiddiqie, istilah "dibagi atas" dimaksudkan untuk menegaskan bahwa hubungan antara Pemerintah Pusat dan Daerah bersifat hirarkis dan vertikal. ${ }^{1}$ Adapun tentang hubungan antara Pemerintah Pusat dan Pemerintah Daerah terdapat di dalam ketentuan Pasal 18 A ayat (1) yang mengatakan bahwa: Hubungan wewenang antara Pemerintah Pusat dan Pemerintahan Daerah provinsi, kabupaten, dan kota, atau antara provinsi dan kabupaten dan kota, diatur dengan undangundang dengan memperhatikan kekhususan dan keragaman daerah. Dijelaskan oleh Jimly Asshiddiqie, bahwa yang dimaksud dengan "kekhususan daerah" adalah kekhususan atau keistimewaan yang terdapat di masing-masing daerah, sedangkan keragaman daerah adalah keragaman antar daerah yang satu dengan daerah lain yang masing-masing berbeda-beda satu sama lain. ${ }^{2}$

Adanya otonomi daerah itulah yang mengakibatkan daerah berlomba-lomba untuk mengatur segala urusan yang berkaitan dengan daerahnya ke dalam Peraturan Darah (Perda), terutama Perda tentang pajak daerah dan retrebusi daerah. Di sisi yang lain, ada sebagian masyarakat di daerah yang menghendaki daerahnya melahirkan Perda-perda yang bernuansa syariah semakin marak, sehingga menimbulkan sikap pro dan kontra. ${ }^{3}$

Penelitian ini difokuskan untuk melakukan pembahasan tentang pengawasan terhadap Qanun sebagai perwujudan wewenang Pemerintah Pusat terhadap otonomi khusus di Nanggroe Aceh Darussalam (untuk selanjutnya ditulis NAD). Kekhususan daerah otonom di NAD meliputi kewenangan-kewenangan sebagai berikut: ${ }^{4} 1$.

${ }^{1}$ Jimly Asshiddiqie, Konsolidasi Naskah UUD 1945 setelah perubahan keempat, Pusat Studi Hukum Tata Negara, FH UI, Jakarta, 2002, hlm. 21

${ }^{2}$ Ibid., hlm. 23

${ }^{3}$ Muhammad Alim, "Perda Bernuansa Syariah dan Hubungannya dengan Konstitusi", artikel dalam Jurnal Hukum Ius Quia Iustum, FH UII, No.1 Vol. 17 Januari 2010, hlm. 120.

${ }^{4}$ Pasal 16 ayat (2) dan Pasal 17 ayat (2) UU No. 11 Tahun 2006. 
penyelenggaraan kehidupan beragama rakyat NAD harus dilandasi oleh ajaran Islam sebagai pedoman dalam pembuatan Qanun. 2. kekhususan NAD lainnya adalah tentang kedudukan hukum adat di NAD; 3. penyelenggaraan pendidikan yang berlandaskan ajaran Islam; 4. peran ulama dalam kehidupan rakyat Aceh, sehingga harus disertakan dalam setiap pembuatan kebijakan daerah (Qanun).

Berdasarkan ketentuan dalam Pasal 1 ayat (2) disebutkan, bahwa Aceh adalah Provinsi yang merupakan kesatuan masyarakat hukum yang bersifat istimewa dan diberi kewenangan khusus untuk mengatur dan mengurus sendiri urusan pemerintahan dan kepentingan masyarakat setempat sesuai dengan peraturan perundang-undangan dalam sistem dan prinsip NKRI berdasarkan UUD 1945, yang dipimpin oleh seorang Gubernur. ${ }^{5}$

Ketentuan pasal di atas menegaskan tentang kedudukan NAD sebagai suatu provinsi dalam kerangka Negara Kesatuan Republik Indonesia selanjutnya disebut NKRI yang bersifat khusus. Kemudian dalam penjelasan umum ${ }^{6}$ menyebutkan bahwa sistem penyelenggaraan pemerintahan NKRI menurut UUD 1945 mengakui dan menghormati satuan-satuan pemerintah daerah yang bersifat khusus atau bersifat istimewa. Perjalanan ketatanegaraan Republik Indonesia menempatkan Aceh sebagai satuan pemerintahan daerah yang bersifat istimewa dengan otonomi khusus, terkait dengan karakter khas sejarah perjuangan masyarakat Aceh yang memiliki ketahanan dan daya juang tinggi. Hal-hal yang mendasar di atas menyebabkan kekhususan bagi daerah NAD yang pelaksanaannya dijabarkan lebih lanjut dalam Qanun.

\section{Rumusan Masalah}

Berdasarkan latar belakang di atas, dapat diidentifikasikan permasalahannya sebagai berikut: Pertama, bagaimana kedudukan Qanun dalam sistem penyelenggaraan pemerintahan Negara Kesatuan Republik Indonesia ? Kedua, bagaimana mekanisme pengawasan Pemerintah Pusat terhadap Qanun di Nanggroe Aceh Darussalam ? Ketiga, apa konsekuensi hukum dari pengawasan Pemerintah Pusat terhadap Qanun di Nanggroe Aceh Darussalam?

\footnotetext{
${ }^{5}$ Pasal 1 ayat (2) UU No.11 tahun 2006.

${ }^{6}$ UU No. 11 Tahun 2006.
} 


\section{Tujuan Penelitian}

Penelitian ini bertujuan untuk mengetahui: Pertama, kedudukan Qanun dalam sistem penyelenggaraan pemerintahan Negara Kesatuan Republik Indonesia. Kedua, mekanisme pengawasan Pemerintah Pusat terhadap Qanun di Nanggroe Aceh Darussalam. Ketiga, konsekuensi hukum dari pengawasan Pemerintah Pusat terhadap Qanun di Nanggroe Aceh Darussalam.

\section{Metode Penelitian}

Metode yang di gunakan dalam penelitian ini adalah metode deskriptif analitis, yaitu penelitian yang memberikan suatu gambaran atau uraian mengenai ruang lingkup dan tinjauan tentang pengawasan Pemerintah Pusat terhadap Qanun di NAD. Metode yang digunakan adalah metode yuridis normatif dengan disertai dengan pendekatan perundang-undangan. ${ }^{7}$

\section{Hasil dan Pembahasan}

\section{Negara Kesatuan dengan Sistem Desentralisasi}

Pada negara yang berbentuk kesatuan, Pemerintah Pusat bertanggung jawab untuk menjamin keutuhan negara kesatuan, karenanya harus dapat menjamin pelayanan yang sama atau keseragaman kepada seluruh rakyat (asas uniformitas), sehingga karena tanggung jawabnya ini penyelenggaraan Pemerintah Pusat cenderung bersifat sentralistik. ${ }^{8}$ Menurut Strong inti dari negara kesatuan adalah:

The essence of a unitary state is that the sovereignty is undivided, or, in other words, that the powers of central government are unrestricted, for the constitution of a unitary state does not admit of any other law-making body than the central one. ${ }^{9}$ (Hakikat negara kesatuan adalah negara yang kedaulatannya tidak terbagi, atau dengan kata lain, negara yang kekuasaan pemerintah pusatnya tidak terbatas karena konstitusi negara kesatuan tidak mengakui adanya badan pembuat undang-undang selain badan pembuat undang-undang pusat).

\footnotetext{
${ }^{7}$ Uraian tentang pendekatan dalam penelitian hukum normatif, lihat Peter Mahmud Marzuki, Penelitian Hukum, Cetk. Kedua, Prenada Media, Jakarta, 2006

${ }^{8}$ Bagir Manan, Hubungan Antara Pusat dan Daerah Menurut UUD 1945, Pustaka Sinar Harapan, Jakarta, 1994 , hlm.17.
} 
Indonesia adalah bentuk negara kesatuan dengan memakai sistem desentralisasi, hal ini juga terdapat di dalam Penjelasan Umum UU No. 32 Tahun 2004 yang mengatakan bahwa : negara Republik Indonesia sebagai negara kesatuan yang menganut asas desentralisasi dalam penyelenggaraan pemerintahannya, dengan memberikan kesempatan dan keleluasaan kepada daerah untuk menyelenggarakan otonomi daerah.

Desentralisasi sebagai suatu sistem yang dipakai dalam bidang pemerintahan berbeda dengan sistem sentralisasi. Pengertian dari sentralisasi adalah suatu pemusatan pada satu titik atau orang, karenanya dalam sistem sentralisasi, segala kewenangan pemerintah baik di Pusat maupun di Daerah dipusatkan dalam satu tangan yaitu Pemerintah Pusat.

Kaitan di antara sentralisasi dan desentralisasi menurut Bayu Surianingrat merupakan pasangan yang tidak dapat dipisahkan, saling berkaitan dan saling mempengaruhi. Menurut Bayu, sentralisasi dan desentralisasi merupakan dua ujung dari sepotong garis. Titik yang bergeser leluasa pada garis yang ditarik antara kedua ujung menunjukkan kadar sentralisasi atau desentralisasi. Bagaimanapun ekstrimnya sentralisasi atau desentralisasi pada suatu organisasi, titik kadar tidak akan berada tepat pada salah satu ujung garis. Jadi kesimpulannya tidak ada sentralisasi tanpa desentralisasi, karena bagaimanapun juga di dalam sentralisasi akan selalu terdapat desentralisasi, demikian pula sebaliknya. ${ }^{10}$

Untuk mengatasi hambatan-hambatan di atas, harus ada keseimbangan di antara Pusat dan Daerah. Untuk menjembatani hubungan yang serasi di antara Pusat dan Daerah, maka asas yang baik untuk negara kesatuan adalah dengan memakai asas desentralisasi. Desentralisasi pada negara kesatuan, berwujud dalam bentuk satuansatuan pemerintah yang lebih rendah (teritorial atau fungsional) yang berhak mengatur dan mengurus sendiri sebagian urusan rumah tangganya. ${ }^{11}$

Agar terjalin hubungan yang serasi di antara Pusat dan Daerah, maka Pemerintah Pusat perlu melakukan pembinaan dan pengawasan terhadap Pemerintah Daerah, hal ini diperlukan dalam suatu negara kesatuan seperti Republik Indonesia yang terdiri dari berbagai macam daerah yang mempunyai kemajemukan,

\footnotetext{
${ }^{9}$ C.F.Strong, Modern Political Constitutions, Sidgwick \& Jackson Limited, London, 1963, hlm. 80 dan 84.

${ }^{10}$ Bayu Surianingrat, Desentralisasi dan Dekonsentrasi Pemerintahan di Indonesia, Suatu Analisa, Dewa Ruci Press, Jakarta, 1981, hlm.1-2.

${ }^{11}$ Bagir Manan, Hubungan..., Op.Cit., hlm. 16.
} 
baik dari segi adat istiadat maupun budaya dan pembentukan pola fikir masyarakatnya yang beragam yang ditentukan oleh sejarah terbentuknya masingmasing daerah. Seperti daerah NAD yang adat istiadatnya banyak didominasi oleh ajaran-ajaran agama Islam sehingga membentuk daerah NAD menjadi daerah yang penduduknya berpola fakir islami.

Pembinaan dari pusat kepada daerah ini perlu dilakukan agar program-program yang dibuat oleh daerah yang berupa peraturan daerah, keputusan daerah atau kebijakan daerah lainnya dapat serasi dan sejalan dengan tujuan Pusat dalam menghantarkan Indonesia menuju Welfare State atau negara kesejahteraan yang menjadi tujuan dari negara. Selain pembinaan, tugas dari pusat kepada daerah yang juga tidak kalah pentingnya adalah pengawasan, karena itu pengawasan yang baik dari pusat kepada daerah dapat menjadikan Republik Indonesia berjalan dengan baik pula.

Menurut Soehino, hubungan antara Pemerintah Pusat dan Pemerintah Daerah merupakan hubungan pengawasan, bukan merupakan hubungan antara bawahan dengan atasan atau hubungan menjalankan pemerintahan seperti halnya hubungan antara pemerintah di daerah yang bersifat administratif atau pemerintah wilayah dengan pusat. ${ }^{12}$ Pengawasan menurut Bagir Manan merupakan pengikat kesatuan, agar bandul kebebasan berotonomi tidak bergerak begitu jauh sehingga mengurangi bahkan mengancam kesatuan, tetapi pengawasan sebagai pengikat tidak juga dapat ditarik begitu kencang, karena akan menyebabkan kebebasan desentralisasi akan berkurang bahkan mungkin terputus. ${ }^{13}$ Menurut Irawan Soejito, pengawasan terhadap segala kegiatan pemerintah daerah itu merupakan suatu akibat mutlak dari adanya negara kesatuan, karenanya dalam penyelenggaraan tugas pemerintahan pada umumnya harus diusahakan selalu adanya keserasian atau harmoni antara tindakan pusat atau negara dengan tindakan daerah, agar kesatuan negara tetap dapat terpelihara. ${ }^{14}$

Pengawasan pusat kepada daerah dimaksudkan agar segala tindakan yang diambil Pemerintah Daerah tidak bertentangan dengan kebijakan-kebijakan yang telah ditetapkan oleh Pemerintah Pusat. Fungsi pengawasan sendiri bukanlah untuk

\footnotetext{
${ }^{12}$ Soehino, Perkembangan Pemerintahan di daerah, Liberty, Yogya, 1995, hlm. 147

${ }^{13}$ Bagir Manan, Hubungan..., Op.Cit., hlm. 181.

${ }^{14}$ Irawan Soejito, Hubungan Pemerintah Pusat Dan Pemerintah Daerah, Rineka Cipta, Jakarta, 1990, hlm.201. Lihat Bagir Manan, Menyongsong Fajar Otonomi Daerah, Cetakan III, PSH Fakultas Hukum UII, Yogyakarta, 2004, hlm. 39-40.
} 
mengekang kebebasan daerah sehingga mematikan langkah-langkah daerah untuk berotonomi dengan luas, tetapi sebagai pengendali agar tindakan-tindakan daerah sesuai dengan peraturan yang berlaku.

\section{Kedudukan Qanun dalam Sistem Penyelenggaraan Pemerintahan di NKRI}

Pengertian Qanun sendiri dalam Kamus Besar Bahasa Indonesia dikenal dengan nama: Kanun, yang artinya adalah : undang-undang, peraturan, kitab undangundang, hukum dan kaidah. ${ }^{15}$ Adapun pengertian Qanun menurut kamus Bahasa Arab adalah: undang-undang, kebiasaan atau adat. ${ }^{16}$ Jadi dapat disimpulkan bahwa pengertian dari Qanun adalah : suatu peraturan perundang-undangan atau aturan hukum yang berlaku di suatu daerah (dalam hal ini di NAD).

Di masyarakat Aceh, penyebutan Qanun terhadap suatu aturan hukum atau untuk penamaan suatu adat telah lama dipakai dan telah menjadi bagian dari kultur adat dan budaya Aceh. Aturan-aturan hukum dan juga adat yang dikeluarkan oleh Kerajaan Aceh banyak yang dinamakan dengan Qanun. Qanun biasanya berisi aturanaturan syariat Islam yang telah beradaptasi menjadi adat istiadat Aceh.

Ketentuan tentang Qanun terdapat di dalam UU No.11 Tahun 2006 tentang Pemerintahan Aceh, yaitu: 1. Qanun Aceh adalah : peraturan perundang-undangan sejenis ${ }^{17}$ peraturan daerah provinsi yang mengatur penyelenggaraan pemerintahan dan kehidupan masyarakat Aceh. ${ }^{18}$ 2. Qanun kabupaten/kota adalah peraturan perundang-undangan sejenis peraturan daerah kabupaten/kota yang mengatur penyelenggaraan pemerintahan dan kehidupan masyarakat kabupaten/kota di Aceh. ${ }^{19}$ Dari ketentuan kedua Pasal di atas, terlihat bahwa maksud dari Qanun dapat disamakan dengan Peraturan Daerah di Provinsi lain di Indonesia, tetapi pada dasarnya pemahaman Qanun yang disamakan dengan Perda sesungguhnya tidaklah tepat. Qanun merupakan suatu peraturan perundang-undangan yang diberlakukan di NAD yang isinya harus berlandaskan pada syariat Islam yang menjadi kekhususan dari NAD, hal ini berbeda dengan daerah lain yang aturan-aturan dalam

\footnotetext{
${ }^{15}$ Pusat Pembinaan Dan Pengembangan Bahasa Departemen Pendidikan Dan Kebudayaan, Kamus Besar Bahasa Indonesia, Balai Pustaka, Jakarta, hlm. 442.

${ }^{16}$ Mahmud Yunus, Kamus Arab-Indonesia, PT Hidakarya Agung, Jakarta, 1989, hlm. 357.

${ }^{17}$ Menurut kamus besar bahasa Indonesia, Op. Cit., hlm. 411, kata sejenis dapat diartikan dengan sebangsa, semacam atau serupa.

${ }^{18}$ Pasal 1 angka 21 UU No. 11 Tahun 2006.

${ }^{19}$ Pasal 1 angka 22 UU No. 11 Tahun 2006.
} 
Perdanya tidak harus berlandaskan ajaran-ajaran Islam. Selain itu berbeda dengan Perda lainnya di Indonesia, aturan-aturan Qanun dapat berisikan aturan-aturan hukum tentang hukum acara material dan formil di Mahkamah Syar'iah.

Jadi pengertian Qanun tidaklah sama dengan Perda, karena isi dari Qanun haruslah berlandaskan pada asas keislaman atau tidak boleh bertentangan dengan syari' at Islam. Tetapi dalam hal hirarki hukum di Indonesia, sesuai dengan ketentuan UU No. 10 Tahun 2004 tentang Pembentukan Peraturan Perundang-undangan, kedudukan Qanun dipersamakan dengan Perda di daerah lainnya. Menurut UU No.10 Tahun 2004 disebutkan bahwa: ${ }^{20}$ jenis dan hierarki peraturan perundangundangan adalah sebagai berikut: UUD RI Tahun 1945, UU/Peraturan Pemerintah Pengganti UU, Peraturan Pemerintah, Peraturan Presiden dan Peraturan Daerah. Pada penjelasan Pasal 7 disebutkan bahwa: Termasuk dalam jenis peraturan daerah provinsi adalah Qanun yang berlaku di Daerah Provinsi Nanggroe Aceh Darussalam dan Perdasus serta Perdasi yang berlaku di Provinsi Papua.

Berdasarkan ketentuan di atas, maka kedudukan Qanun diakui dalam hierarki perundang-undangan Indonesia dan dipersamakan dengan Perda. Pemahaman dalam UU No. 10 Tahun 2004 ini dapat saja diterima dalam hal kedudukan Qanun. Pemahaman ini akan lebih mempermudah Pemerintah Pusat dalam melakukan pengawasan dan pembinaan terhadap daerah, terutama yang berhubungan dengan pembentukan suatu kebijakan daerah. Hanya saja tetap harus diperhatikan tentang kekhususan yang diberikan Pusat terhadap NAD. Contohnya saja, berdasarkan kekhususan yang di berikan Pusat kepada NAD, maka DPR Aceh dapat mensahkan Qanun tentang jinayat atau peradilan pidana Islam sebagai hukum acara di Mahkamah Syar'iah. Hanya saja memang produk dari Qanun ini harus memenuhi syarat-syarat yang harus dipenuhi oleh Pemerintahan Aceh seperti tidak boleh bertentangan dengan: aqidah, syar'iyah dan akhlak yang dalam penjabarannya meliputi: ibadah, ahwal al-syakhshiyah (hukum keluarga), muamalah (hukum perdata), jinayah (hukum pidana), qadha' (peradilan), tarbiyah (pendidikan), dakwah, syiar dan pembelaan Islam. ${ }^{21}$ Kebijakan ini tentu tidak diperbolehkan dibuat oleh perda-perda lainnya di Indonesia.

Berdasarkan hasil penelitian tentang kedudukan dari Qanun ini, dapat disimpulkan bahwa pengertian Qanun dapat saja dianggap "sejenis" (atau menurut

\footnotetext{
${ }^{20}$ Pasal 7 UU No. 10 Tahun 2004.

${ }^{21}$ Lihat ketentuan dalam Pasal 125 UU No. 11 Tahun 2006.
} 
Kamus Besar Bahasa Indonesia diartikan sebagai : semacam, serupa) ${ }^{22}$ dengan Perda, tetapi dari segi isinya berbeda, karena Qanun mempunyai keistimewaan yang tidak dipunyai oleh daerah-daerah lain di Indonesia.

Adapun kedudukan Qanun terdapat di dalam peraturan perundang-undangan sebagai berikut: 1. UU No. 18 Tahun 2001 tentang Otonomi Khusus Bagi Provinsi Daerah Istimewa Aceh Sebagai Provinsi Nanggroe Aceh Darussalam. Kedudukan Qanun terdapat di dalam Pasal 1 angka 8 yang mengatakan bahwa : Qanun Provinsi NAD adalah peraturan daerah sebagai pelaksanaan undang-undang di wilayah Provinsi NAD dalam rangka penyelenggaraan otonomi khusus; 2. UU No. 10 Tahun $2004^{23}$ tentang Pembentukan Peraturan Perundang undangan. Penjelasan Pasal 7 ayat (2) a, yang mengatakan bahwa: Termasuk dalam jenis peraturan daerah provinsi adalah Qanun yang berlaku di daerah NAD dan perdasus serta perdasi yang berlaku di propinsi Papua; 3. UU No. 11 Tahun 2006 tentang Pemerintahan Aceh. Pasal 21 dan 22 menyatakan bahwa : Qanun adalah peraturan perundang-undangan sejenis peraturan daerah yang mengatur penyelenggaraan pemerintahan dan kehidupan masyarakat Aceh.

\section{Mekanisme Pelaksanaan Pengawasan Pusat Terhadap Qanun di Nanggroe Aceh Darussalam}

Pada dasarnya mekanisme pengawasan pusat terhadap Qanun sama dengan pengawasan pusat terhadap perda di daerah lainnya. Dimulai dari pembuatan perda atau Qanun sampai dengan pelaksanaan perda atau Qanun, tetapi yang menjadi persoalan adalah pengawasan terhadap Qanun yang berisi aturan-aturan tentang pelaksanaan syariat Islam.

Pada pembuatan, pelaksanaan sera pengawasannya, Qanun dapat dibagi menjadi dua katagori yaitu: Qanun Umum dan Qanun Khusus. Pembagian Qanun menjadi dua katagori ini dikarenakan : Pertama, isi dari Qanun yang berbeda antara Qanun umum dan Qanun khusus. (1) Qanun Umum, yaitu Qanun yang berisi aturanaturan tentang penyelenggaraan pemerintahan secara umum. Isi Qanun umum ini mempunyai persamaan dan perbedaan dengan ketentuan atau isi perda daerah lainnya. Persamaannya, isinya berisi tentang ketentuan-ketentuan umum dalam hal

\footnotetext{
${ }^{22}$ Kamus Besar Bahasa Indoensia, Op. Cit., hlm. 411.

${ }^{23}$ Telah dicabut dan dinyatakan tidak berlaku oleh UU No. 12 Tahun 2011 tentang Pembentukan Peraturan Perundang-undangan.
} 
penyelenggaraan pemerintahan seperti di bidang: pajak, retribusi, APBD, RUTR, dan semua urusan yang diberikan pusat kepada daerah diluar urusan atau kewenangan pusat. Adapun perbedaannya dengan peraturan daerah lainnya adalah: bahwa setiap isi Qanun tidak boleh bertentangan dengan ajaran Islam. (2) Qanun Khusus, yaitu Qanun yang berisi aturan-aturan tentang penyelenggaraan kekhususan pemerintahan daerah NAD. Kriteria Qanun khusus yaitu: a. kehidupan beragama di NAD harus dilandasi oleh ajaran Islam. b. kehidupan hukum adat haruslah berlandaskan ajaran Islam. c. penyelenggaraan pendidikan haruslah berdasarkan ajaran Islam. d. Peran Ulama sangat penting sebagai pemuka agama, karena itu Ulama harus di ikut sertakan dalam pembuatan Qanun, agar kebijakan yang dibuat tidak bertentangan dengan ajaran Islam yang telah menjadi Volksgeist atau jiwa bangsa dari masyarakat Aceh.

Kedua, berdasarkan mekanisme pengawasannya. (a) pengawasan terhadap Qanun umum, yang dilaksanakan sesuai dengan ketentuan yang telah diatur dalam UU No. 32 Tahun 2004 yaitu: pengawasan preventif dan pengawasan represif. (b) pengawasan terhadap Qanun khusus. Pengawasan terhadap Qanun ini diatur dalam UU No. 11 Tahun 2006 yang mengatakan bahwa: ${ }^{24}$ (1) pengawasan pemerintah terhadap Qanun dilaksanakan sesuai dengan peraturan perundang-undangan. (2) Pemerintah dapat membatalkan Qanun yang bertentangan dengan : kepentingan umum, antar Qanun dan peraturan perundang-undangan yang lebih tinggi kecuali di atur lain dalam undang-undang ini. (3) Qanun dapat diuji oleh Mahkamah Agung sesuai dengan peraturan perundang-undangan. (4) Qanun sebagaimana dimaksud pada ayat (3) yang mengatur tentang pelaksanaan syari'at Islam hanya dapat dibatalkan melalui uji materi oleh Mahkamah Agung. (5) Sebelum disetujui bersama antara Gubernur dan DPRA serta bupati/walikota dan DPRK, pemerintah mengevaluasi rancangan Qanun tentang APBA dan Gubernur mengevaluasi rancangan APBK. (6) Hasil evaluasi sebagaimana dimaksud pada ayat (5) bersifat mengikat Gubernur dan bupati/walikota untuk dilaksanakan

Berdasarkan ketentuan Pasal di atas, terlihat bahwa terdapat perbedaan dalam mekanisme pengawasan yang dilakukan pusat terhadap Qanun. Terhadap Qanun yang bersifat umum dilakukan melalui mekanisme yang di atur dalam UU No. 32 Tahun 2004, sedangkan pengawasan terhadap Qanun khusus berdasarkan Pasal 235

${ }^{24}$ Pasal 235 UU No. 11 Tahun 2006. 
ayat (4) UU No. 11 Tahun 2006 yaitu: Qanun yang mengatur tentang pelaksanaan syariat Islam hanya dapat dibatalkan melalui uji material oleh Mahkamah Agung.

Terlihat dari ketentuan di atas bahwa Pemerintah Pusat tidak dapat membatalkan pemberlakuan suatu Qanun yang bersifat khusus yang berisi pelaksanaan syariat Islam. Hal ini menimbulkan permasalahan tersendiri, karena konsekuensi dari suatu pengawasan adalah berupa revisi, penangguhan atau pembatalan suatu Qanun.

Pengawasan Pusat terhadap Qanun mutlak diperlukan, agar penyelenggaraan pemerintahan di NAD dapat berjalan dengan baik dan lancar, oleh karenanya diperlukan perubahan terhadap Pasal 235 ayat (4) UU No. 11 Tahun 2006 yaitu yang mengatakan: Qanun yang mengatur tentang pelaksanaan syari'at Islam hanya dapat dibatalkan melalui uji materiil oleh Mahkamah Agung, karenanya perlu dibuat suatu mekanisme pengawasan terhadap Qanun khusus, agar fungsi pengawasan yaitu sebagai pembatas terhadap kekuasaan daerah dapat berjalan dengan baik.

Berdasarkan hasil penelitian ini, di dapat suatu rumusan mekanisme pengawasan terhadap Qanun khusus ini yaitu : mekanisme pengawasan represif. Pengawasan represif dianggap terbaik bagi pusat untuk mengawasi Qanun khusus ini didasari pertimbangan bahwa: (1) Walaupun pada dasarnya pemerintah Aceh menginginkan bila yang dapat membatalkan pemberlakuan Qanun khusus itu hanya Mahkamah Agung saja, tetapi harus menjadi perhatian bahwa daerah NAD masuk dalam wilayah NKRI, karena itu pengawasan pusat terhadap Qanun mutlak harus ada. Hal ini didasari karena bentuk negara yang dipilih di Indonesia adalah negara kesatuan. Dalam negara kesatuan pelaksanaan penyelenggaraan otoritas tertinggi berada dalam satu kekuasaan pusat. Hakikat negara kesatuan sendiri adalah negara yang kedaulatannya yang tidak terbagi. Demikian pula dalam pengawasan terhadap Qanun, harus dilakukan oleh pusat sebagai konsekuensi dari negara kesatuan. (2) Pengawasan represif ini dianggap lebih baik, karena NAD masih dapat membuat Qanun khusus tersebut tanpa harus menunggu penilaian dari pusat terlebih dahulu, sehingga NAD tidak merasa di intervensi oleh pusat. Hal ini perlu diperhatikan oleh pemerintah pusat, karena pada dasarnya pemerintah Aceh masih mempunyai sifat curiga kepada pusat.

\section{Konsekuensi Hukum dari Pengawasan Pemerintah Pusat terhadap Qanun di NAD}

Ketentuan tentang pengawasan dan konsekuensi hukum yang timbul dari pengawasan Pusat terhadap Qanun tercantum dalam Pasal 235 UU No. 11 Tahun 
2006: (1) pengawasan pemerintah terhadap Qanun dilaksanakan sesuai dengan peraturan perundang-undangan. (2) Pemerintah dapat membatalkan Qanun yang bertentangan dengan : kepentingan umum, antar Qanun dan peraturan perundangundangan yang lebih tinggi kecuali di atur lain dalam undang-undang ini. (3) Qanun dapat diuji oleh Mahkamah Agung sesuai dengan peraturan perundang-undangan. (4) Qanun sebagaimana dimaksud pada ayat (3) yang mengatur tentang pelaksanaan syari'at Islam hanya dapat dibatalkan melalui uji materi oleh Mahkamah Agung. (5) Sebelum disetujui bersama antara Gubernur dan DPRA serta bupati/walikota dan DPRK, pemerintah mengevaluasi rancangan Qanun tentang APBA dan Gubernur mengevaluasi rancangan APBK (6) Hasil evaluasi sebagaimana dimaksud pada ayat (5) bersifat mengikat Gubernur dan bupati/walikota untuk dilaksanakan.

Dari ketentuan Pasal di atas ada beberapa hal menarik yang dapat dicermati yaitu: (1) indikator dari pembatalan Qanun adalah apabila bertentangan dengan : kepentingan umum, apabila bertentangan dengan antar Qanun dan peraturan perundang-undangan yang lebih tinggi kecuali di atur lain dalam undang-undang ini. (2) pada ketentuan ayat (4) disebutkan bahwa terhadap Qanun yang berisikan ketentuan tentang kekhususan yaitu mengatur pelaksanaan syariat Islam hanya dapat dibatalkan melalui hak uji material oleh Mahkamah Agung.

Qanun dibentuk dalam rangka penyelenggaraan pemerintahan Aceh, pemerintahan kabupaten/kota dan penyelenggaraan tugas pembantuan. Penyelenggaraan pemerintahan daerah di NAD berbeda dengan penyelenggaraan pemerintahan di daerah lainnya, dimana NAD mendapat kekhususan dalam hal menjalankan syariat Islam. Karenanya dalam pembuatan Qanun di NAD dibedakan dalam dua bagian, yaitu: (1) Qanun yang memuat kebijakan-kebijakan penyelenggaraan pemerintahan secara umum (untuk selanjutnya disebut Qanun Umum), dalam artian sama dengan perda lainnya di Indonesia dan, (2) Qanun yang berisi kebijakan-kebijakan penyelenggaraan pemerintahan secara khusus (untuk selanjutnya disebut Qanun Khusus) yang diberikan kepada NAD.

Dari ketentuan Pasal 235 ayat (1) UU No. 11 Tahun 2006 terlihat bahwa pengawasan terhadap Qanun dilakukan oleh pemerintah sesuai dengan peraturan perundang-undangan. Jadi dapat ditegaskan di sini bahwa Pemerintah yang mengawasi pelaksanaan dari Qanun, baik itu Qanun umum atau Qanun khusus. Konsekuensi dari pengawasan menurut peraturan perundang-undangan adalah berupa: evaluasi, revisi, penangguhan, sampai dengan pembatalan Qanun. 
Pengawasan Qanun dilakukan oleh Pemerintah, karenanya sudah seharusnya bila pemerintah dapat memberikan konsekuensi hukum terhadap Qanun yang diawasinya. Tetapi yang menjadi kerancuan dalam tata cara berfikir hukum tata negara dalam UU No. 11 Tahun 2006 adalah, bahwa untuk Qanun khusus, konsekuensi hukum yang berupa pembatalan hanya dapat dilakukan melalui hak uji material di Mahkamah Agung. Terlihat di sini bahwa pemerintah pusat tidak dapat membatalkan Qanun khusus.

Seyogyanya, pemerintah pusat dapat membatalkan Qanun yang dianggap bertentangan dengan peraturan perundang-undangan yang telah ditentukan, apapun bentuk Qanun itu, apakah berbentuk Qanun khusus ataupun berbentuk Qanun umum, hal ini berkaitan dengan bentuk pemerintahan yang di pilih bangsa Indonesia yaitu berbentuk negara kesatuan. Konsekuensi dari pertanggungjawaban itu adalah dapat diterima atau tidaknya kebijakan penyelenggaraan pemerintahan itu. Jadi sudah sewajarnya bila pemerintah pusat dapat memberikan sanksi-sanksi hukum kepada daerah berupa revisi, penanguhan atau pembatalan suatu Qanun. Jika NAD tidak berkenan dengan pembatalan Qanun tersebut, dapat pengajukan keberatannya kepada Mahkamah Agung melalui mekanisme pengujian secara material.

Di Indonesia terjadi dualisme pengaturan penilaian atau pengujian terhadap Peraturan Daerah (dan juga Qanun), yaitu pengujian yang dilakukan oleh Pemerintah sebagai badan administrasi dan pengujian yang dilakukan oleh Mahkamah Agung sebagai badan yudisial. Pada dasarnya pengawasan terhadap suatu peraturan daerah adalah wewenang dari pemerintah pusat sebagai lembaga eksekutif untuk mengawasinya, adapun Mahkamah Agung adalah lembaga yudisial yang hanya dapat melakukan pengujian setelah dimintakan pendapatnya melalui permintaan untuk melakukan hak uji material.

Dualisme ini terlihat dalam ketentuan yang mengatakan bahwa pemerintah dapat membatalkan peraturan daerah, ${ }^{25}$ ketentuan ini yang melandasi pusat untuk melakukan pengawasan terhadap Perda/Qanun, dan dapat memberi sanksi berupa pembatalan bila Perda/Qanun itu dianggap bertentangan dengan kepentingan umum, peraturan perundang-undangan yang lebih tinggi dan peraturan daerah lainnya. Selanjutnya kepada daerah yang tidak dapat menerima keputusan pembatalan peraturan daerah dapat mengajukan keberatan kepada Mahkamah Agung setelah mengajukannya kepada Pemerintah.

${ }^{25}$ Lihat ketentuan Pasal 145 (5), (6) UU No. 32 Tahun 2004. 
Ketentuan ini yang melandasi MA untuk melakukan hak uji material terhadap Perda/Qanun. Hak uji material sendiri dimaksudkan agar MA dapat menilai apakah isi dari Perda/ Qanun yang dianggap bermasalah itu telah sesuai atau tidak dengan peraturan perundang-undangan yang berlaku.

Kewenangan MA untuk menguji Perda terdapat di dalam Pasal 24 A (1) Perubahan ke 3 UUD 1945 yang mengatakan bahwa :Mahkamah Agung berwenang mengadili pada tingkat kasasi, menguji peraturan perundang-undangan di bawah undang-undang terhadap undang-undang, dan mempunyai wewenang lainnya yang diberikan oleh undang-undang. Dualisme terhadap pengujian Perda yang terdapat dalam peraturan perundang-undangan di Indonesia ini menimbulkan ketidakpastian, siapakah yang lebih berhak memutuskan kata akhir, apakah pengujian secara yudisial ataukah pengujian secara non yudisial.

Berdasarkan hasil penelitian dapat disimpilkan bahwa, konsekuensi dari adanya suatu pengawasan pusat terhadap Qanun baik Qanun umum dan Qanun khusus adalah berupa: kewenangan pusat untuk merevisi, menangguhkan atau membatalkan suatu Qanun yang dianggap bertentangan dengan kepentingan umum, peraturan perundang-undangan yang lebih tinggi, serta Qanun yang bertentangan dengan ajaran Islam yang menjadi jiwa bagi masyarakat Aceh.

\section{Penutup}

Substansi Qanun tidak sama dengan peraturan daerah, karena isi dari Qanun haruslah berlandaskan pada asas keislaman atau tidak boleh bertentangan dengan syari' at Islam. Tetapi dalam hal hirarki hukum di Indonesia, sesuai dengan ketentuan UU No. 10 Tahun 2004 tentang Pembentukan Peraturan Perundang-undangan dan UU No. 11 Tahun 2006 tentang Pemerintah Aceh, pengertian Qanun disamakan dengan peraturan daerah di daerah lainnya.

Berdasarkan ketentuan dalam UU No. 11 Tahun 2006, isi Qanun dibagi menjadi dua, yaitu Qanun Umum dan Qanun Khusus. a) mekanisme pengawasan terhadap Qanun Umum adalah berupa pengawasan represif dan preventif. Pengawasan represif yaitu dengan meneliti atau memeriksa Qanun yang disampaikan pemerintahan NAD kepada pusat, dalam hal ini dilakukan oleh Menteri Dalam Negeri dan Otonomi Daerah. Pemerintah Pusat dapat melimpahkan pengawasan kepada Gubernur selaku Wakil Pemerintah terhadap Qanun yang dibuat oleh 
Pemerintah Daerah Kabupaten dan Kota setelah berkoordinasi dengan instansi terkait. Selain itu untuk menjaga kepastian hukum, maka pengawasan pusat terhadap Qanun tidak bisa hanya memakai pengawasan represif saja, tetapi juga harus memakai pengawasan preventif. Bentuk pengawasan preventif ini selain dalam hal mengesahkan atau tidak mengesahkan Perda, juga dalam hal bimbingan, petunjuk dan rambu-rambu, sehingga pemerintahan NAD dapat menghasilkan Qanun yang dapat diterima oleh semua kalangan, baik pusat maupun masyarakat NAD. b) adapun mekanisme pengawasan terhadap Qanun Khusus adalah : pengawasan represif. Hal ini didasarkan kepada pertimbangan sebagai berikut : (1) dalam negara kesatuan pelaksanaan penyelenggaraan otoritas tertinggi berada dalam satu kekuasaan pusat. Hakikat negara kesatuan sendiri adalah negara yang kedaulatannya yang tidak terbagi. Demikian pula dalam pengawasan terhadap Qanun, harus dilakukan oleh pusat sebagai konsekuensi dari negara kesatuan. (2) pengawasan represif ini dianggap lebih baik, karena NAD masih dapat membuat Qanun khusus tersebut tanpa harus menunggu penilaian dari pusat terlebih dahulu, sehingga NAD tidak merasa di intervensi oleh pusat. c) fungsi pengawasan terhadap Qanun khusus dapat berjalan dengan baik bila dibuat suatu lembaga atau badan pengawas yang mengawasi dari mulai pembuatan Qanun sampai dengan pelaksanaan Qanun khusus, agar sesuai dengan tujuan NKRI yaitu negara kesejahteraan.

Konsekuensi dari adanya pengawasan Pusat terhadap Qanun, baik Qanun Umum atau Qanun Khusus adalah berupa : kewenangan Pusat untuk merevisi, menangguhkan atau membatalkan suatu Qanun yang dianggap bertentangan dengan: kepentingan umum, peraturan perundang-undangan yang lebih tinggi, serta Qanun yang bertentangan dengan ajaran Islam yang menjadi jiwa bagi masyarakat Aceh.

\section{Daftar Pustaka}

Alim, Muhammad, "Perda Bernuansa Syariah dan Hubungannya dengan Konstitusi", Jurnal Hukum Ius Quia Iustum, FH UII, No.1 Vol. 17 Januari 2010.

Asshiddiqie, Jimly, Konsolidasi Naskah UUD 1945 Setelah Perubahan Keempat, Pusat Studi Hukum Tata Negara, FH UI, Jakarta, 2002.

Mahmud Marzuki, Peter, Penelitian Hukum, Cetk. Kedua, Prenada Media, Jakarta, 2006. 
Manan, Bagir, Hubungan Antara Pusat dan Daerah Menurut UUD 1945, Pustaka Sinar Harapan, Jakarta, 1994.

Menyongsong Fajar Otonomi Daerah, Cetakan III, PSH Fakultas Hukum UII, Yogyakarta, 2004.

Soehino, Perkembangan Pemerintahan di daerah, Liberty, Yogya, 1995.

Soejito, Irawan, Hubungan Pemerintah Pusat Dan Pemerintah Daerah, Rineka Cipta, Jakarta, 1990.

Strong, C.F., Modern Political Constitutions, Sidgwick \& Jackson Limited, London, 1963.

Surianingrat, Bayu, Desentralisasi dan Dekonsentrasi Pemerintahan di Indonesia, Suatu Analisa, Dewa Ruci Press, Jakarta, 1981.

Yunus, Mahmud, Kamus Arab-Indonesia, PT Hidakarya Agung, Jakarta, 1989.

UU No. 11 Tahun 2006 tentang Pemerintahan Aceh.

UU No. 32 Tahun 2004 tentang Pemerintahan Daerah. 